\title{
Diffüz alopesili kadınlarda öfke, anksiyete ve depresyon
}

\author{
Anger, anxiety and depression in females with diffuse alopecia
}

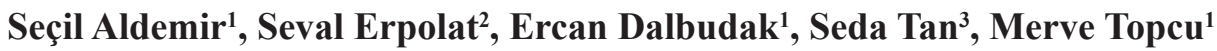

\section{ÖZET}

Amaç: Bu çalışmada diffüz alopesili hastalarda psikiyatrik belirti sıklığının sağlıklı kontrollere göre daha fazla olup olmadığının belirlenmesi ve bunların öfke düzeyleriyle ilişkisinin araştırılması amaçlanmıştır.

Yöntemler: Bu çalışmaya dermatoloji polikliniğinde diffüz alopesi tanısı konulan 43 kadın hasta ile cinsiyet ve yaş açısından uyumlu sağlıklı 52 gönüllü dâhil edildi. Dermatolojik tanı olarak diffüz alopesi alt tiplerinden androgenetik alopesi tanısı alan 19 (\%20,0), diffüz alopesia areata tanısı alan $10(\% 10,5)$, telogen effluvium tanısı alan 14 $(\% 14,7)$ kişi çalışmaya dâhil edildi. Hastalara ve kontrol grubuna Hastane Anksiyete ve Depresyon Ölçeği (HAD) ve Sürekli Öfke ve Öfke Tarz Ölçeği (SÖÖTÖ) uygulandı. Standart hazırlanan "Saç Dökülmesi Hasta Takip Formu"na hastaların kayıtları yapıldı.

Bulgular: Alopesili hasta grubunda sağlıklı kontrollere göre anksiyete $(p<0.001)$ ve depresyon $(p<0.001)$ puanları anlamlı olarak yüksek bulunmuştur. Ayrıca sürekli öfke $(\beta=0,216$, Wald $Z=3,697, \operatorname{Exp}(B)=1,241, p<0,05)$ ve anksiyete $(\beta=-0.466$, Wald $Z=5,008, \operatorname{Exp}(B)=0.628$, $p<0,05)$ puanlarının tanı grubunu anlamlı derecede öngördüğü ve ayırt edici olduğu belirlendi. Saç dökülme süresinin, anlamlı ölçüde depresyon $(r=0,402, p<0.01)$ ve anksiyete $(r=0,393, p<0.01)$ puanları ile pozitif korelasyon gösterdiği bulundu. Dermatolojik tanılar birbirleriyle karşılaştırıldığında, sürekli öfke ve öfke dışa alt ölçekleri arasında anlamlı derecede farklılıklar saptandı.

Sonuç: Alopesili hastalarda sağlıklı kontrollere göre anksiyete ve depresif belirtilerin daha fazla olduğu tespit edilmiştir. Bu hastalara bu tür psikiyatrik rahatsızlıklar sıklıkla eşlik ettiği için psikiyatri kliniği ile işbirliği yapılması; hem tedavinin başarısını, hem de hastanın yaşam kalitesini olumlu yönde etkileyecektir. Ayrıca bu hastalarda öfke ve öfke ifade tarzı üzerinde de dikkatle durulmalıdır. Bu ilişkinin farkında olmak diffüz alopesi hastalarının tedavisine katkı sağlayacaktır.

Anahtar kelimeler: Diffüz alopesi, depresyon, anksiyete, öfke

\begin{abstract}
Objective: Present study aims to compare control group patients and patients with diffuse alopecia in order to understand the nature of the relationship between symptoms and level of anger and to see whether patient group has higher number of symptoms than control group.
\end{abstract}

Methods: 43 female patients who were diagnosed diffuse alopecia in dermatology clinic and 52 age-andgender-matched control participants were included in the study. $20 \%$ of patients $(n=19)$ with androgenetic alopecia, $10.5 \%$ of patients $(n=10)$ with diffuse alopecia areata and $14.7 \%$ of patients $(n=14)$ with telogen effluvium participated in study. Hospital Anxiety and Depression Scale (HADS) and The Trait Anger and Anger Expression Scale (TAAES) were filled by the participants. Also patients were followed up by a standard hospital form recording alopecia.

Results: It was found that patients with alopecia revealed significantly more depression $(p<0,001)$ and anxiety $(p<0,001)$ scores than control group. Also trait anger $(\beta=$ $0,216$, Wald $Z=3,697, \operatorname{Exp}(B)=1,241, p<0,05)$ and anxiety $(\beta=-0.466$, Wald $Z=5,008, \operatorname{Exp}(B)=0.628, p<0,05)$ scores significantly predicted alopecia group. Additionally total time period for alopecia significantly and positively correlated with depression $(r=0,402, p<0.01)$ and anxiety $(r=0,393, p<0,01)$ scores. Comparing patient groups with each other, trait anger and expressed anger were significantly different across groups.

Conclusion: Patient group reported more anxiety and depressive symptoms than control group. In treatment of patients with alopecia, bidirectional relationship between alopecia and psychological symptoms should be in consideration. Collaboration with psychiatry is suggested in order to improve treatment efficacy and patients' life satisfaction. In addition anger management seems essential in treatment of patients with diffuse alopecia.

Key words: Diffuse alopecia, depression, anxiety, anger

\footnotetext{
${ }^{I}$ Turgut Özal Üniversitesi Tıp Fakültesi Psikiyatri AD, Ankara, Türkiye

${ }^{2}$ Turgut Özal Üniversitesi Tıp Fakültesi Dermatoloji AD, Ankara, Türkiye

${ }^{3}$ Gazi Üniversitesi Doktora Öğrencisi, Ankara, Türkiye
}

Yazışma Adresi /Correspondence: Seçil Aldemir,

Turgut Özal Üniversitesi Tıp Fakültesi Psikiyatri AD, Ankara, Türkiye Email:drsecilozen@gmail.com

Geliş Tarihi / Received: 14.05.2015, Kabul Tarihi / Accepted: 01.07.2015

Copyright (C) Dicle Tıp Dergisi 2015, Her hakkı saklıdır / All rights reserved 


\section{GíRiş}

Saç, kişiliğin ve sosyal rolün fiziksel ifadesidir. $\mathrm{Bu}$ yüzden genellikle saç kaybı bireye sıkıntı veren bir durumdur [1]. Alopesi her yaştaki kadın ve erkeği etkileyebilen, psikososyal olarak kişileri rahatsız eden bir durumdur. Saç hayatın devamı için gerekli olmamakla birlikte kişinin imajı için çok önemlidir. Saç sayısında, yapısında ve dağılımında en küçük değişiklik hastanın doktora başvurmasına neden olur [2]. Alopesi yaşamı tehdit edici veya ağrılı olmamasına rağmen, duygusal strese ve azalmış benlik saygısına sebep olabilir [3]. Saç kaybı kadınlarda erkeklere göre daha fazla stres yaratır [4]. Özellikle kadınları etkileyen ve yaygın bir şikayet olan diffüz alopesi (DA) dermatoloji pratiğinde önemli bir sorundur [5].

Alopesiler geleneksel olarak skar dokusunun olup olmamasina ve lokalize veya diffüz bir paternin oluşuna göre sınıflandırılırlar. Sık görülen klinik bir problem olan diffüz, skarsız bir saç dökülmesi şikayeti ile kadınlar dermatoloji polikliniğine başvururlar [6]. DA'nın kadın androgenetik alopesi (KAA) veya kadın tipi saç dökülmesi, kronik telogen effluvium (TE), ve diffüz alopesi areata (DAA) şeklinde üç ana tipi vardır [5]. En sık görülen DA tipi telojen efluvium (TE) olup olguların çoğu subklinik olduğu için gerçek insidansı bilinmemektedir [7]. DAA, alopesi areataların (AA) en az görülen klinik tipidir [6]. Alopesinin farklı türleri değişik psikiyatrik rahatsızlıklara yol açabilirler. AA çok şiddetli bir formdur ve diğerlerinden daha fazla medikal tedaviye yanıt verir [8]. Tüm saçlı deride saç kaybı şeklinde olan DA, bazen androgenetik alopesi (AGA) olarak ortaya çıkabilir [9]. AGA kadınlarda aynı zamanda kadın tipi (female patern) saç kaybı olarak da bilinir, kadınlarda sık görülen bir saç kaybıdır [10]. DA birçok hormonal, çeşitli kimyasal maddelere, besinsel faktöre, ilaçlara, sistemik/kutanöz hastalıklara ve emosyonel strese bağlı olarak ortaya çıkabilir [9] ya da emosyonel strese sebep olabilir [11].

Alopesili kişilerde majör depresif bozukluk, anksiyete bozukluğu, sosyal fobi gibi psikiyatrik rahatsılıkların görülme ihtimali genel populasyondan daha yüksektir [12]. Alopesili kadınlarda yaşam kalitesi ile alopesileriyle baş etmeleri arasındaki ilişkiyi araştıran bir çalışmada, daha fazla saç dökülmesi olan hastalarda daha fazla olumsuz emosyonel stres saptanmıştır. Saç dökülmesi fazla olmayan gruptaki hastalarda da psikiyatrik bozukluklar görülmüştür [13]. Cash ve arkadaşlarının AGA'lı kadın ve erkekler üzerinde yaptıkları çalışmada AGA'lı kadınlarda daha fazla psikolojik negatif etkilerin ortaya çıktığını bildirmişlerdir [4]. AA'lı hastalarda yapılan bir çalışmada, hastalarda yaygın anksiyete bozukluğu, depresif bozukluk yüksek oranda olduğu bildirilmiştir [14]. Camacho ve arkadaşları AGA'lı kadın ve erkeklerde yaptıkları çalışmalarında kadınlarda depresyonu erkeklerden daha fazla bulurken anksiyeteyi ise erkeklerde daha fazla saptamışlardır [15].

Alopesinin hasta tarafindan algilanan olumsuz etkileri arasinda anksiyete ve depresif belirtilerin yanı sıra öfke de sayılabilir [16]. Öfke psikodermatolojik hastalıklarda major rol oynar [17]. Bireylerin olumsuz duygularından olan öfke, bedende bağışıkl1k sistemini ve hormonal düzeni bozmaktadır [18]. Öfke, somatizasyon gelişiminde önemli bir etken olarak tanımlanmıştır. Öfke ifade tarzı ile somatik belirtiler arasındaki ilişkinin incelendiği bir araştırmada; öfke dişavurumunun depresif bozukluklardaki somatizasyonla anlamlı ilişki gösterdiği gözlenmiştir [19]. Alopesi de psikosomatik bir hastalık olarak kabul edilmektedir [14]. Kişiliğin bir parçası olarak kabul edilen [20] öfke ifade tarzlarından içe dönük öfkenin psikosomatik bozukluklarla, somatoform bozukluklarla ve kaygı bozukluklarıyla anlamlı ilişki gösterdiği tespit edilmiştir [19]. Öfke açısından incelendiğinde, erkek alopesi olgularında kadınlardan daha fazla saldırganlığın olduğuna dikkat çekilmiştir [15]. Alopesi areatalı hastaların sağlıklı kontrollerle karşılaştırıldığ 1 bir çalışmada ise öfke puanlarında anlamlı farklılık saptanmamıştır [21].

Literatürde DA'nın üç tipini de içeren kişiliğin bir uzantısı olan öfke-öfke ifade tarzları ile bunlara eşlik eden psikiyatrik bozukluklar ile ilgili yapılmış çalışma bulunmamaktadır. Bu nedenle bu çalışmada DA'lı hastalarda anksiyete ve depresif belirtilerin sıklığının sağlıklı kontrollere göre daha fazla olup olmadığını belirlenmesi ve bunların öfke düzeyleriyle ilişkisinin araştırılması amaçlanmıştır.

\section{YÖNTEMLER}

Araştırmaya hastanemiz dermatoloji polikliniğine diffüz saç dökülmesi şikayetiyle başvuran 43 kadın hasta ile bu hastalarla benzer yaş grubunda olan 52 
sağl1klı gönüllü kontrol grubu olarak alındı. Çalışmaya başlamadan önce, hastane etik kurulundan gerekli onay ve izin alınarak tüm katılımcılar çalışma hakkında bilgilendirildi ve onayları alındı. Okuma yazma bilmeyen, yeterli iletişim kurulamayan ve mental retardasyonu olan hastalar çalışmaya alınmadi.

Standart hazırlanan "Saç Dökülmesi Hasta Takip Formu"na hastaların kayıtları yapıldı. Saç dökülmesinin süresi, günlük dökülen yaklaşı saç sayısı, saç dökülmesi için tedavi alıp almadığı, sistemik hastalık ve/veya alınan diğer ilaçlar, beslenme alışkanlığ1, diyet, psikolojik stres, ameliyat öyküsü, hamilelik, mensturasyon ve menopoz durumları sorguland1. Dermatolojik muayene ile alopesi tipi, yaygınlığı, lokalizasyonu belirlendi ve saç çekme testi uygulandı. Tüm hastalarda tam kan sayımı, serum demir, serum demir bağlama kapasitesi, ferritin, vitamin B12, folik asit ve tiroid fonksiyon testleri değerlendirildi. Gereken olgularda ise DHEAS, serbest ve total testosteron, ANA ve VDRL tetkikleri istendi. Dermatolojik muayene sonucunda DA'nın AGA, TE ve DAA tipleriyle uyumlu, kan tetkiklerinde anormallik saptanmayan 43 kadın hasta çalışma kapsamına alındı.

Kontrol grubu olarak, hastalarla yaş, cinsiyet ve eğitim düzeyi açısından eşleştirilmiş halen ve geçmişinde psikiyatrik hastalık öyküsü olmayan, herhangi bir dermatolojik hastalığı bulunmayan hastane personeli ve yakınlarından oluşan 52 sağlıklı kontrol çalışmaya dahil edildi.

Çalışmaya alınma koşullarını karşılayan hasta ve sağlıklı kontroller için sosyodemografik veri formu doldurularak Hastane Anksiyete ve Depresyon Ölçeği (HAD) ve Sürekli Öfke ve Öfke Tarz Ölçeği (SÖÖTÖ) uyguland1.

\section{VERI TOPLAMA ARAÇLARI}

\section{Sosyodemografik ve Klinik Bilgi Veri Formu}

Hasta ve kontrol grubunun genel bilgilerini içeren bu formda, yaş, cinsiyet, medeni durum, alışkanlıklar, kullandığ 1 ilaçlar, ekonomik durum, psikiyatrik ve fiziksel hastalık öyküsü, hastalık süresi yer almaktadir.

\section{Hastane Anksiyete ve Depresyon Ölçeği (HAD)}

Hastada anksiyete ve depresyon yönünden riski belirlemek, düzeyini ve şiddet değişimini ölçmek amacıyla uygulanan kendini değerlendirme ölçeğidir. Toplam 14 soru içermekte ve bunların yedisi anksiyeteyi ve diğer yedisi depresyonu ölçmektedir [22].

Aydemir ve arkadaşlarının [23] yaptıkları geçerlik ve güvenirlik çalışması sonucunda anksiyete alt ölçeği için kesme puanı 10/11, depresyon alt ölçeği için ise 7/8 bulunmuştur. Buna göre bu puanların üzerinde alanlar risk altında olarak değerlendirilir.

Çalışmamızda anksiyete için kesme puanı 10 , depresyon için kesme puanı 7 olarak kabul edildi.

\section{Sürekli Öfke ve Öfke Tarz Ölçeği (SÖÖTÖ)}

Sürekli öfke ve öfkeyi ifade etme ölçeği Spielberger ve arkadaşları tarafından geliştirilmiştir [24]. Ölçeğin Türkçe geçerliği ve güvenirliği Özer tarafından yapılmıştır [25]. Ölçek; 34 maddeden oluşmakta olup, sürekli öfke, kontrol altına alınmış öfke, dışa vurulmuş öfke, bastırılmış öfke alt ölçekleri bulunmaktadır. Geçerlik güvenirlik çalışmasında Chronbach Alfa değerleri; sürekli öfke boyutu için 0.79, kontrol altına alınmış öfke boyutu için 0.84 , dışa vurulmuş öfke boyutu için 0.78 ve öfke içte boyutu için ise 0.62 olarak bulunmuştur. Ölçekteki ilk on maddenin toplamı ile sürekli öfke alt ölçeği, 13, 15, $16,20,23,26,27$ ve 31 no'lu maddelerin toplami ile öfke içte alt ölçeği, 12, 17, 19, 22, 24, 29, 32 ve 33 no'lu maddelerin toplamı ile öfke dişa alt ölçeği, 11 , $14,18,21,25,28,30$ ve 34 no'lu maddelerin toplamı ile öfke kontrol alt ölçeği puanları elde edilir. Sürekli öfkeden alınan yüksek puanlar, öfke düzeyinin yüksek olduğunu; kontrol öfke ölçeğinden al1nan yüksek puanlar öfkenin kontrol edilebildiğini, öfke dışa ölçeğinden alınan yüksek puanlar, öfkenin kolayca ifade edilebiliyor olduğunu ve öfke içte alt ölçeğinden alınan yüksek puanlar ise öfkenin bastırılmış olduğunu göstermektedir.

\section{İstatistiksel Analiz}

Çalışmada elde edilen verilerin istatistiksel analizleri için, SPSS (Stastical Package for Social Sciences) for Windows 16.0 programı kullanıldı. İstatistiksel değerlendirmelerde normal dağılıma uyan verilerin çözümlemesinde $\mathrm{T}$ testi, normal dağılıma uymayan verilerin çözümlemesinde ise Kruskall Wallis testi, pearson korelasyon testi yapıldı. Ölçümle elde edilen veriler aritmetik ortalama \pm standart sapma, sa- 
yımla elde dilen veriler ise sayı ve yüzde (\%) olarak gösterildi. İstatistiksel değerlendirmede anlamlılık düzeyi olarak $\mathrm{p}<0,05$ olarak kabul edildi.

\section{BULGULAR}

Araştırmaya 43 hasta 52 kontrol olmak üzere 95 kişi alındı. Hasta grubunda yer alanların yaş ortalaması $27,5 \pm 7,4$ y1l, kontrol grubundakilerin yaş ortalamas1 ise 27,6 $6 \pm$,4 y1l olarak belirlendi. Hasta ve kontrol grubu arasında yaş ortalaması bakımından anlam11 farklılik bulunmadi $(\mathrm{p}>0,05)$. Dermatolojik tan 1 olarak DA alt tiplerinden AGA tanıs1 alan $19(\% 20$ $.0)$, DAA tanis1 alan 10 (\%10.5), TE tanis1 alan 14 $(\% 14,7)$ kişi çalışmaya dahil edildi. Hastaların ortalama saç dökülme süresi $17,04 \pm 21,32$ ay idi. Kat1lımcıların eğitim ve medeni durumlarının dağılımı Tablo 1'de özetlenmiştir.

Tablo 1. Diffüz alopesili hastalarla ve sağlıklı kontrollerin sosyodemografik özellikleri, n (\%)

\begin{tabular}{|c|c|c|c|}
\hline & $\begin{array}{l}\text { Diffüz alopesi } \\
(n=43)\end{array}$ & $\begin{array}{c}\text { Kontrol } \\
(n=52)\end{array}$ & p \\
\hline Yaş(yıl) (OrttsS) & $27.53 \pm 7.38$ & $27.55 \pm 7.39$ & \\
\hline \multicolumn{4}{|l|}{ Medeni durum } \\
\hline Evli & $23(53,5)$ & $25(48,1)$ & \\
\hline Bekar & $20(46,5)$ & $27(51,9)$ & 0.953 \\
\hline \multicolumn{4}{|l|}{ Eğitim } \\
\hline İlköğretim & $5(11,6)$ & $3(5,8)$ & \\
\hline Lise & $8(18,6)$ & $3(5,8)$ & \\
\hline Üniversite & $30(69,8)$ & $46(88,5)$ & \\
\hline
\end{tabular}

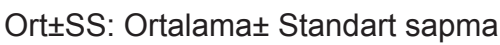

Saç dökülme süresi, anksiyete, depresyon, sürekli öfke, öfke içe, öfke dişa ve öfke kontrol değişkenlerinin birbiri ile korelasyonları değerlendirildi (Tablo 2). Saç dökülme süresinin, anlamlı ölçüde depresyon değişkeni $(r=0,402, p<0.01)$ ve anksiyete $(\mathrm{r}=0,393, \mathrm{p}<0.01)$ değişkeni ile pozitif korelasyon gösterdiği belirlendi.

Dermatolojik tanı alan katılımcılar ve kontrol grubu, saç dökülme süresi, anksiyete, depresyon, sürekli öfke, öfke içe, öfke dişa ve öfke kontrol ortalama skorları bakımından karşılaştırıldı. Student $\mathrm{T}$ test analizi sonuçlarına göre dermatolojik tanı alan grup, kontrol grup ortalamaları ile karşılaştırildığında saç dökülme süresi $(\mathrm{p}<0.001)$, anksiyete $(\mathrm{p}<0.001)$ ve depresyon $(\mathrm{p}<0.001)$ bakımından an- lamlı düzeyde farklı olduğu belirlendi. Sırasıyla saç dökülme süresi, anksiyete ve depresyon değişkenleri grup ortalamalarının (7.12 ve 4,72), kontrol grubu ortalamalarından (0.44 ve 0.29$)$ daha yüksek olduğu belirlendi (Tablo 3 ).

Tablo 2. Saç dökülmesi, Depresyon, Anksiyete ve Öfke Alt Ölçekleri arasındaki korelasyonel ilişki

\begin{tabular}{|c|c|c|c|c|c|c|}
\hline & 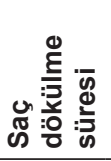 & 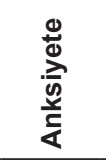 & 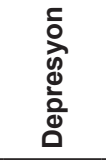 & 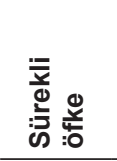 & 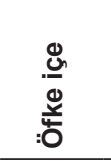 & 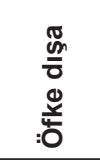 \\
\hline Anksiyete & $0,393^{* *}$ & 1 & & & & \\
\hline Depresyon & $0,402^{* *}$ & $0,853^{* *}$ & 1 & & & \\
\hline Sürekli öfke & 0,574 & $0,244^{*}$ & 0,169 & 1 & & \\
\hline Öfke içe & 0,897 & 0,021 & $-0,023$ & $0,356^{* *}$ & 1 & \\
\hline Öfke dışa & 0,128 & 0,072 & 0,097 & $0,633^{* *}$ & $0,306^{* *}$ & 1 \\
\hline Öfke kontrol & 0,065 & $-0,026$ & 0,012 & $-0,545^{* *}$ & $-0,106$ & $-0,503^{* *}$ \\
\hline
\end{tabular}

** $p<0.01,{ }^{*} p<0.05$

Tablo 3. Diffüz alopesili hastalarla ve sağlıklı kontrollerin anksiyete, depresyon ve öfke puanları ve karşılaştırması (Ortalama \pm Standart sapma)

\begin{tabular}{lccc}
\hline & $\begin{array}{c}\text { Diffüz alopesi } \\
(\mathbf{n = 4 3 )}\end{array}$ & $\begin{array}{c}\text { Kontrol } \\
(\mathbf{n = 5 2 )}\end{array}$ & $\mathbf{p}$ \\
\hline Dökülme süresi & $17.05 \pm 21.32$ & $0.02 \pm 0.14$ & $<0.001$ \\
Anksiyete & $7.12 \pm 3.99$ & $0.44 \pm 2.40$ & $<0.001$ \\
Depresyon & $4.72 \pm 2.58$ & $0.29 \pm 1.49$ & $<0.001$ \\
Sürekli öfke & $21.42 \pm 5.66$ & $21.75 \pm 5.67$ & 0.938 \\
Öfke içe & $15.02 \pm 3.27$ & $16.60 \pm 4.48$ & 0.180 \\
Öfke dışa & $15.28 \pm 3.30$ & $15.25 \pm 4.30$ & 0.158 \\
Öfke kontrol & $22.19 \pm 4.16$ & $21.33 \pm 5.34$ & 0.079 \\
\hline
\end{tabular}

Tanı gruplarında eşit sayıda katılımcı olmaması nedeni ile tanı grup ortalamalarının karşılaştırılması amacıyla nonparametrik test uygulanmıştır. Katılımcılar dermatolojik tanılarına göre saç dökülme süresi, anksiyete, depresyon, sürekli öfke, öfke içe, öfke dıșa ve öfke kontrol bakımından karşılaștırılmıştır. Kruskall Wallis test sonuçları, dermatolojik tanılara göre, sürekli öfke $(\mathrm{p}=0.004)$ ve öfke dişa alt $(\mathrm{p}=0.018)$ ölçekleri bakımından anlamlı derecede farklı olduğu belirlendi. Tanı grupları arasında sürekli öfke alt ölçek ortalamaları karşılaştırıldığında DAA'lı hastaların ortalamaları (30 ve 65), TE $(24,9)$ ve AGA $(15,32)$ hastaların ortalamalarından daha yüksek bulunmuştur. Öfke dişa alt ölçek puanları arasındaki karşılaştırmada ise DAA hastala- 
rının ortalamaları $(31,7)$, TE $(17,9)$ ve AGA $(19,9)$ hastalarının ortalamalarından daha yüksek olduğu saptand.

Anksiyete, depresyon ve öfke değişkenlerinin tanı grubunu öngörme düzeyini belirlemek amacıyla lojistik regresyon analizi yapılmıştır. Model anlamli bulundu $(\chi 2=82,915, \mathrm{p}<0.001)$. Lojistik analizi sonucu değerlendirildiğinde sürekli öfke $(\beta=0,216$, Wald $Z=3,697, \operatorname{Exp}(B)=1,241, p=$ $0,045)$ ve anksiyetenin $(\beta=-0.466$, Wald $Z=5,008$, $\operatorname{Exp}(B)=0.628, p=0,025)$ tan 1 grubunu anlaml1 derecede öngördüğüı ve ayırt edici olduğu belirlendi.

\section{TARTIŞMA}

Saç, kadınlar için sembolik olarak erkeklere kıyasla daha fazla cinsellik ve kişilikle bağlantılıdır. Nitekim, genellikle bir kadının benlik saygısı erkeğe göre fiziksel görünüme daha çok bağlıdır ve kadının fiziksel olarak çekici bir birey olup olmadığ konusunda saçın etkisi çok fazladır [26]. Kimlik ve saç arasındaki bağlantı özellikle kadınlar için çok önemlidir. Saç dökülmesi olan kadın fiziksel görünüm olarak toplum normlarına uymadığı için kendisini anormal ve başarısız olarak görebilir [27]. $\mathrm{Bu}$ nedenle çalışmamızda diffüz alopesisi olan kadınların psikiyatrik sorunlarının daha fazla olacağı düşünülerek bu grupta yer alan 43 kadın hasta çalışmaya dahil edildi.

Schmidt ve arkadaşları alopesili kadınların yaşam kalitesi ile alopesileri ile baş etmeleri arasındaki ilişkiyi açıklamaya çalışmışlardır. Daha fazla saç dökülmesi olan hastalarda daha fazla negatif emosyonel durumlar, negatif kendine güven ve negatif stigmatizasyon görülmüştür. Bir grup hastada fazla saç dökülmesi olmamasına rağmen psikiyatrik bozukluklar görülmüştür [13]. Çalışmamızda saç dökülme süresi arttıkça anksiyete ve depresif belirtiler artmaktadır. Gupta ve arkadaşları [28] çalışmalarında çalışmamızla uyumlu olarak alopesili hastalarda depresyon skorlarının yüksek olduğu ve bu bulgunun hastalık şiddeti ile korelasyon gösterdiğini saptamışlardır.

Alopesinin oluşturduğu görünüm bozukluğunun depresyona sebep olabileceği bildirilmektedir [29]. AA'lı hastalarda yapılan bir çalışmada, hastaların \%66'sında yaygın anksiyete bozukluğu, uyum bozukluğu ve depresif bozukluk olduğu bildirilmiş- tir [14]. Cash ve arkadaşları 96 AGA'lı kadın ve 60 AGA'lı erkekten oluşan çalışmalarının sonucunda AGA'lı kadınlarda daha fazla psikolojik negatif etkilerin ortaya çıktığını bildirmişlerdir [4]. Camacho ve arkadaşları AGA'lı kadın ve erkeklerde yaptıkları çalışmada kadınlarda depresif belirtilerin daha fazla, erkeklerde ise anksiyete ve agresyonunun daha fazla olduğunu bulmuşlardır [15]. Çalışmamızda anksiyete ve depresif belirtiler alopesili hastalarda sağlıklı kontrollerden daha fazla bulunmuştur. Colon ve arkadaşları AA'lı hastaların \%74'ünün yaşamları boyunca, başta major depresyon ve yaygın anksiyete olmak üzere en az bir kez psikiyatrik hastalık tanısı aldığını bildirmişlerdir [30]. Bizim sonuçlarımız Çalıkoğlu ve arkadaşlarının [31] AA'lı hastalarda depresyon ve anksiyete bulguları açısından sağl1klı kontrollere göre fark olmadığ 1 şeklindeki sonuçlarına ters düşmektedir. Ülkemizde yapılan mevcut çalışmalardan farklı olarak, depresif belirtilerin hasta grubumuzdaki belirgin yüksekliği dikkat çekicidir [32]. Alfani ve arkadaşları tarafından yapılan çalışmada alopesili hastaların anksiyete ve depresyon puanlarının kontrollerden daha fazla olduğu saptanmıştır [21]. AGA'lı hastalarda yapılan çalışmada depresyon ve anksiyete yaygınlığının kadınlarda erkeklerden daha fazla olduğu tespit edilmiştir [33]. Anksiyete ve depresyon belirtilerinin hastalarda kontrollere göre daha belirgin olması, kültürel faktörlerle ilgili olarak kadınların dış görünümlerini daha fazla önemsediklerini göstermektedir.

Saç dökülmesi olan kadınlarda beden imajıyla ilgili memnuniyetsizlik öfkeye sebep olmaktadır [4]. DA' da baş etme mekanizmalarından maladaptif olanlar arasında sosyal içeçekilme ve başkalarına karşı öfke sayılabilir [13]. AA'lı hastaların sağlıklı kontrollerle MMPI-2 uygulanarak karşılaştırıldığ 1 çalışmada öfke alt ölçek puanlarında anlamlı farklılık saptanmamıştır [21]. Çalışmamızda da hastalarla sağlıklı kontroller arasında karşılaştırma yapıldığında öfke ve öfke ifade tarzları arasında anlamlı farklılık bulunamamıştır. Fakat DA alt tipleri arasında yapılan karşılaştırmada anlamlı farklılık saptanmış ve DAA'nın sürekli öfke ve öfke dışa alt ölçeklerinin ortalama skorlarının AGA ve TE ortalamalarından daha fazla olduğu bulunmuştur. DAA tipinin diğerlerine göre çok şiddetli görülen bir DA formu olması [8] bu sonuçlarımızı açılayabilir. Kadın ve erkek AGA hastaları arasında yapılan bir çalışmada 
erkeklerde öfke ve hostilite düzeyinin kadınlardan daha fazla olduğu tespit edilmiştir [15]. Doruk ve arkadaşlarının yaptığı çalışmada psöriyazis, alopesi areata ve sağlıklı kontrol grupları arasında aleksitimi, öfke-öfke ifade tarzları ile mizaç ve karakter boyutlarında farklılık saptanmamıştır [34].

Depresyon ve anksiyetenin alopesinin oluşumuna zemin hazırladığı bildirilmektedir [29]. Alopesili hastaların \%93'ünde ciddi bir psikiyatrik hastalık bulunduğu sonucuna varan araştırmalar olduğu gibi [35], psikiyatrik rahatsızlıkların patogenezde rol oynadığı saptanan araştırmalar da bulunmaktadır [15]. Yazıcı ve arkadaşlarının yaptığı çalışma ise AA patogenezinde stresli yaşam olayları, depresyon ve anksiyete gibi psikopatolojilerin rol oynadığı görüşünü desteklememektedir [32]. Çalışmada lojistik analizi sonucu değerlendirildiğinde sürekli öfke ve anksiyetenin tanı grubunu anlamlı derecede yordadığ 1 ve ayırt edici olduğu belirlenmiştir. Sonuçlar alopesi patogenezinde gerek öfke ve öfke ifade tarzlarının gerekse de depresyon ve anksiyete olmak üzere psikolojik faktörlerin rol oynadığı görüşünü desteklemektedir.

Sonuç olarak bu hastalıklara sıklıkla psikiyatrik rahatsızlıklar eşlik ettiğinden psikiyatrik sorunları olan hastalarda psikiyatri kliniği ile işbirliği yapılması; hem tedavinin başarısını, hem de hastanın yaşam kalitesini olumlu yönde etkileyecektir. Hastaya, uygun psikolojik destekle birlikte saç döngüsü ve etkili kozmetik iyileşme için sabırlı olunması gerektiği yönünde eğitim verilerek hastanın anksiyetesinin azaltılması sağlanabilir. Psikiyatristler ve dermatologların özellikle kadınlarda beden imajını olumsuz olarak etkileyen hastalığın başlangıcında ve devamında da önemli olduğu düşünülen öfke, anksiyete ve depresif belirtileriyle başa çıkabilmek için işbirliği içinde olması bu hastaların daha kolay tedavi edilmesini sağlayacaktır. Bununla birlikte öfke ve öfke ifade tarzlarını araştırmak için daha geniş örneklem gruplarıyla birlikte çalışmalar yapılmasına ihtiyaç olduğu düşünülmektedir.

\section{KAYNAKLAR}

1. Biondo S, Goble D, Sinclair R. Women who present with female pattern hair loss tend to underestimate the severity of their hair loss. Br J Dermatol 2004;150:750-752.
2. Wolff H. Diseases of hair. Braun-Falco's Dermatology. Ed. Burgdorf WHC, Plewig G, Wolff HH, Landthaler M, Braun-Falco O. 3rd ed. Italy, Springer, 2009;1029-1059.

3. Firooz A, Firoozabadi MR, Ghazisaidi B, Dowlati Y. Concepts of patients with alopecia areata about their disease. BMC Dermatol 2005;5:1.

4. Cash TF, Price VH, Savin RC. Psychological effects of androgenetic alopecia on women: comparisons with balding men and with female control subjects. J Am Acad Dermatol 1993;29:568-575.

5. Werner B, Mulinari-Brenner F. Clinical and histological challenge in the differential diagnosis of diffuse alopecia: female androgenetic alopecia, telogen effluvium and alopecia areata--part II. An Bras Dermatol 2012;87:884-890.

6. Chartier MB, Hoss DM, Kels JMG. Approach to the adult female patient with diffuse

nonscarring alopecia. J Am Acad Dermatol 2002;47:809-818.

7. Harrison S, Sinclair R. Telogen Effluvium. Clin Exp Dermatol 2002;27:389-395.

8. Baranda L, Layseca-Espinosa E, Abud-Mendoza C, Gonzàlez- Amaro R. Severe and unresponsive HIV-associated alopecia areata successfully treated with thalidomide. Acta Derm Venereol 2005;85:277-278.

9. Trueb RM. Diffuse hair loss in women. Ther Umsch 2002;59:217-222

10. Price VH. Androgenetic alopecia in women. J Invest Dermatol 2003;8:24-27.

11. Trueb RM. Systematic approach to hair loss in women. J Dtsch Dermatol Ges 2010;8:284-297.

12. Harth W, Blume-Peytavi U. Psychotrichology: psychosomatic aspects of hair diseases. J Dtsch Dermatol Ges 2013; 11:125-135

13. Schmidt S, Fischer TW, Chren MM, et al. Strategies of coping and quality of life in women with alopecia. Br J Dermatol 2001;144:1038-1043.

14. Ruiz-Doblado S, Carrizosa A, García-Hernández MJ. Alopecia areata: psychiatric comorbidity and adjustment ofilness. Int J Dermatol 2003;42:434-437.

15. Camacho FM, Hernandez MJG. Psychological features of androgenetic alopecia. J Eur Acad Dermatol Venereol 2002; $16: 476-480$

16. Hadshiew IM, Foitzik K, Arck PC, Paus R. Burden of hair loss: Stress and the underestimated psychosocial impact of telogen effluvium and androgenetic alopecia. J Invest Dermatol 2004;123:455-457.

17. Altınöz AE, Taşkıntuna N, Altınöz ST, Ceran S. A cohort study of the relationship between anger and chronic spontaneous urticaria. Adv Ther 2014;31:1000-1007.

18. Bağcıŏlu E. Akne vulgariste psikolojik faktörlerin rolü, hastalığın yaşam kalitesi üzerine etkisi. Yayımlanmamış Uzmanlık Tezi, Sütçü İmam Üniversitesi Tıp Fakültesi Psikiyatri Anabilim Dalı, Kahramanmaraş, 2008. 
19. Koh KB. Anger and somatization. Journal of Psychosomatic Research 2003;55:113.

20. Sifneos PE. Alexithymia and its relationship to hemispheric specialization, affect, and creativity. Psychiatr Clin North Am 1988;11:287-292.

21. Alfani S, Antinone V, Mozzetta A, et al. Psychological status of patients with alopecia areata. Acta Derm Venereol 2012;92:304-306.

22. Zigmond AS, Snaith RP. The hospital anxiety and depression scale. Acta Psychiatr Scand 1983;67:361-370.

23. Aydemir Ö. Hastane anksiyete ve depresyon ölçeği türkçe formunun geçerlilik ve güvenilirlik çalışması. Türk Psikiyatri Dergisi 1997;8:280-287.

24. Spielberger CD, Jacobs GA, Russell SF, Crane RJ. Assessment of anger: The state-trait anger scale. Advances in personality assessment. Ed. Butcher JN, Spielberger CD. Hillsdale NJ, Erlbaum, 1983; 159-187.

25. Özer AK. Sürekli öfke ve öfke ifade tarzı ölçekleri ön çalışmas1. Türk Psikoloji Dergisi 1994;31:26-35.

26. Cash TF. The psychology of hair loss and its implications for patient care. Clin Dermatol 2001;19:161-166.

27. Cartwright T, Endean N, Porter A. Illness perceptions, coping and quality of life in patients with alopecia. Br J Dermatol 2009;160:1034-1039.
28. Gupta MA, Gupta AK, Wattell GN. Stress and alopecia areata: psychodermatologic study. Acta Derm Venereol 1997;77:296-298

29. Mercan S, Altunay İK. Psikiyatri ve dermatolojinin ortak çalışma alanı: Psikodermatoloji. Türk Psikiyatri Dergisi 2006; 17:305-313.

30. Colon EA, Popkin MK, Callies AL, et al. Lifetime prevalence of psychiatric disorders in patients with alopecia areata. Comprehensive Psychiatry 1991;32:245-251.

31. Çalıkoğlu E, Alpay FB. Pruri universalis, alopecia areata, psoriasis vulgaris ve kronik ürtikerde Beck depresyon, durumluluk ve süreklilik kaygı envanterlerinin değerlendirilmesi. T Klin Dermatol 2000;10:229-232.

32. Yazıcı AC, Başterzi A, Tot Acar Ş, et al. Alopesi Areata ve Aleksitimi. Türk Psikiyatri Dergisi 2006;17:101-106.

33. Tabolli S, Sampogna F, di Pietro C, et al. Health status, coping strategies and alexithymia in subjects with androgenetic alopecia: a questionnaire study. Am J Clin Dermatol 2013;14:139-145.

34. Doruk A, Tunca M, Koç E, ve ark. Psöriyazis ve alopesi areatali erkek olgularda aleksitimi, öfke-öfke ifade tarzi ve mizaç-karakter özellikleri. Turkiye Klinikleri J Med Sci 2009;29:1503-1509.

35. Greenberg SI. Alopecia areata: a psychiatric survey. Arch Dermatol 1995;72:454-457. 